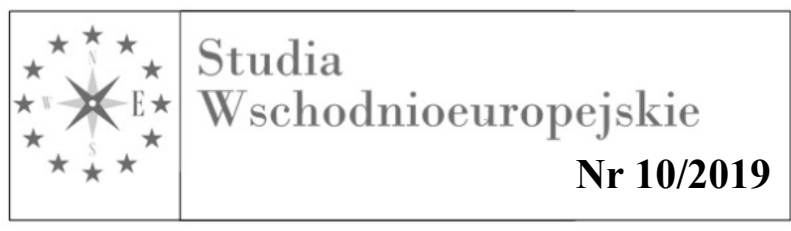

\title{
Zapewnienie bezpieczeństwa Mistrzostw Świata w Piłce Nożnej w 2018 roku jako narzędzie do osiągnięcia sukcesu propagandowego Kremla
}

F ederacja Rosyjska, podobnie jak wiele innych państw, prowadzi świadomą politykę - sportową, której znaczenie istotnie wzrosło w okresie rządów Władimira Putina. Stanowi ona w znacznej mierze rozbudowaną kontynuację założeń przyjętych jeszcze w ZSRR, dostosowaną do warunków współczesnego świata i sportu. Jedną z jej podstawowych cech jest jej niemal całkowite podporządkowanie rosyjskim aspiracjom politycznym. Do najważniejszych celów władz rosyjskich w dziedzinie sportu zaliczyć można m.in. organizowanie wielkich imprez sportowych. Wydarzenia takie mają za zadanie przede wszystkim wypromowanie Rosji na arenie międzynarodowej jako nowoczesnego i silnego państwa, dysponującego znacznymi możliwościami organizacyjnymi. Wpisuje się to w ramy jednego z głównych postulatów Władimira Putina - przywrócenia Rosji rangi mocarstwa globalnego, a nie tylko regionalnego. Przykładami takich imprez mogą być chociażby: Mistrzostwa Świata w Piłce Nożnej w 2018 roku, Zimowe Igrzyska Olimpijskie w 2014 roku czy chociażby Mistrzostwa Świata w Lekkoatletyce w 2013 roku $^{343}$.

Za przedmiot analizy w niniejszym artykule posłużył wspomniany mundial w Rosji jako przykład z jednej strony najbardziej aktualny, a z drugiej jako przypadek wymagający największych nakładów i stanowiący największe wyzwanie dla służb. Po pierwsze w odróżnieniu od innych imprez sportowych skoncentrowanych wokół jednego ośrodka np. Soczi w przypadku igrzysk z 2014 roku, mistrzostwa odbywały się aż w 11 rosyjskich miastach. Były to miasta o różnym poziomie zagrożenia, niektóre - jak Wołgograd, Rostów nad Donem czy Soczi, położone są w bezpośrednim sąsiedztwie Kaukazu, utożsamianego z kolebką terroryzmu islamskiego w Rosji. Często były to miejsca oddalone od siebie o setki a nawet tysiące kilometrów, wobec czego należało zabezpieczyć nie tylko same miasta, ale również środki komunikacji funkcjonujące pomiędzy nimi. Jeżeli wziąć pod uwagę również fakt, że konieczne było zapewnienie bezpieczeństwa wszystkim reprezentacjom narodowym, stacjonującym w trakcie mistrzostw w różnych ośrodkach, nakłady te należy pomnożyć kilkukrotnie. Niezbędne stało się zabezpieczenie szeregu mniejszych miejscowości, takich jak przykładowo Jessentuki (baza reprezentacji Nigerii) czy Gelendżyk (baza reprezentacji Islandii i Szwecji) oraz tych, które uznać można za szczególnie niebezpieczne, takich jak stolica Czeczenii - Grozny (baza reprezentacji Egiptu) ${ }^{344}$. Po drugie, dodatkowe trudności mógł

\footnotetext{
343 Więcej o cechach, celach oraz uwarunkowaniach rosyjskiej polityki sportowej w: A. Podleśny, Polityka sportowa Zwiqzku Radzieckiego i Federacji Rosyjskiej, Warszawa 2019.

${ }^{344} \mathrm{O}$ należyte przyjęcie reprezentacji Egiptu zatroszczył się osobiście sam Ramzan Kadyrow - prezydent Czeczenii. Na uroczystym przyjęciu dla gości z Egiptu wręczył Mohamedowi Salahowi (największej gwieździe reprezentacji, napastnikowi Liverpool F.C.) kopię dekretu na mocy którego nadano mu honorowe obywatelstwo Czeczenii i pamiątkową odznakę. Zdjęcia z uroczystości odbiły się szerokim echem w mediach i portalach społecznościowych. Stały się argumentem dla krytyków Kadyrowa, którzy zarzucali mu, że ewidentnie chciał wypromować swój wizerunek przy pomocy gwiazdy piłki nożnej.
} 
stwarzać czas trwania imprezy, która odbywała się w dniach od 14 czerwca do 15 lipca 2018 roku, czyli przez ponad miesiąc. Utrzymanie całkowitego bezpieczeństwa przez tak długi okres, zwłaszcza na obszarach podwyższonego ryzyka mogło stanowić poważne wyzwanie dla służb.

Jednym z warunków sine qua non dla osiągnięcia zamierzonego celu politycznego i wizerunkowego było zapewnienie całkowitego bezpieczeństwa w trakcie Mistrzostw Świata w Piłce Nożnej. Niepowodzenie tego zadania mogłoby niemal całkowicie zniweczyć zakładany przez władze propagandowy sukces imprezy. Do najważniejszych rodzajów zagrożeń mogących zakłócić przebieg wydarzenia można zaliczyć:

1. Niebezpieczeństwo zamachów terrorystycznych - zwłaszcza ze strony organizacji terrorystycznych wywodzących się z Północnego Kaukazu,

2. Niebezpieczeństwo zamachów na VIP-ów, zwłaszcza na głowy państw i rządów przybywających do Rosji w celu obejrzenia meczu ${ }^{345}$,

3. Niebezpieczeństwo ze strony rosyjskich pseudokibiców, znanych z agresywnych zachowań, ale również ze szczególnie piętnowanych przez międzynarodowe organizacje sportowe, incydentów o charakterze rasistowskim,

4. Niebezpieczeństwo masowych protestów i wystąpień publicznych, które nadwątliłyby kreowany przez władze pozytywny wizerunek i nie mogłyby być, na oczach zagranicznych gości i mediów, stanowczo zwalczane przez służby bezpieczeństwa,

5. Niebezpieczeństwo w postaci drobnych przestępstw oraz spekulowania cenami usług i towarów, na które narażeni byli w największym stopniu zwykli kibice z innych państw oraz ewentualnej aktywności zorganizowanych grup przestępczych.

\section{Działania organizacyjne i legislacyjne}

Federacja Rosyjska została wybrana gospodarzem mundialu w grudniu 2010 roku. Dzięki temu władze miały ponad 7 lat na odpowiednie przygotowanie się do imprezy, również na gruncie legislacyjnym. $\mathrm{Z}$ odpowiednim wyprzedzeniem wprowadzone zostało specjalne ustawodawstwo, mające na celu zapewnienie bezpieczeństwa $w$ trakcie imprezy. Najważniejszymi dokumentami były: Zasady zachowania się widzów podczas oficjalnych zawodów sportowych, zatwierdzone Rozporządzeniem Rządu Federacji Rosyjskiej nr 1156 z dnia 16 grudnia 2013 r. ${ }^{346}$ oraz Dekret Prezydenta Rosji z dnia 9 maja 2017 r. nr $202 \mathrm{~W}$ sprawie cech zastosowania wzmocnionych środków bezpieczeństwa podczas Mistrzostw Świata FIFA 2018 i Pucharu Konfederacji FIFA 2017 w Rosji ${ }^{347}$. W myśl przyjętych przepisów zabrania się m.in. zakrywania twarzy, przebywania w stanie nietrzeźwości na terenie obiektów

\footnotetext{
345 Pomimo wielu zapowiedzi bojkotu rosyjskiego mundialu, ostatecznie na przyjazd nie zdecydowali się jedynie przedstawiciele władz Wielkiej Brytanii, Islandii i Polski (spośród państw reprezentowanych w rozgrywkach). Obecni byli natomiast szefowie rządów lub głowy państw takich krajów jak chociażby: Francja, Niemcy, Portugalia, Węgry oraz Chorwacja, a także monarchowie Belgii i Hiszpanii.

346 Постановление Правительства РФ от 16.12.2013 N 1156 (ред. от 30.01.2014) «Об утверждении Правил поведения зрителей при проведении официальных спортивных соревнований».

347 Указ Президента России от 9 мая 2017 года №202 «Об особенностях применения усиленных мер безопасности в период проведения в РФ чемпионата мира по футболу FIFA 2018 года и Кубка конфедераций FIFA 2017 года».
} 
sportowych oraz wnoszenia tam alkoholu, nielegalnego handlu biletami, obrażania innych osób, wnoszenia na stadion pirotechniki, a nawet popularnych ,wuwuzel” i napojów w szklanych opakowaniach. Ustawodawstwo przewiduje również przepisy sanacyjne za złamanie wymienionych powyżej zakazów. W myśl ich brzmienia można zostać ukaranym grzywną od trzech tysięcy do dziesięciu tysięcy rubli lub pracami społecznymi w wymiarze do stu godzin, połączonymi z ,zakazem stadionowym” przez okres od sześciu miesięcy do nawet trzech lat. Inne przypadki nagannego zachowania popełnione przez cudzoziemca lub bezpaństwowca, będące poniżej progu przestępstwa, skutkują grzywną w wysokości od dziesięciu tysięcy do dwudziestu tysięcy rubli połączoną z przymusowym wydaleniem z Federacji Rosyjskiej lub aresztem administracyjnym na okres do piętnastu dni wraz z przymusowym wydaleniem z Federacji Rosyjskiej. Dla kibiców wprowadzono system identyfikacji „FanID”, którego wydania władze mogły odmówić, bez podania przyczyny - w praktyce, najczęściej w wypadku podejrzenia o możliwość zachowań chuligańskich. Świadczyć o tym może m.in. przypadek Aleksandra Szprygina - prezesa Wszechrosyjskiego Związku Kibiców (WOB), któremu odmówiono przyznania „FanID”, bez podania jakiejkolwiek przyczyny. Decyzję podjęła arbitralnie Federalna Służba Bezpieczeństwa.

Znacząco zaostrzono również przepisy dotyczące posiadania broni palnej - wszyscy jej posiadacze na ponad dwa miesiące stracili uprawnienia do jej noszenia i używania. Niemożliwy stał się obrót bronią zarówno sportową, myśliwską, jak i przeznaczoną do obrony osobistej. W wielu wyznaczonych strefach zakazywano na dwa dni (dzień przed meczem i w dniu meczu) sprzedaży alkoholu w szklanych butelkach, które mogłyby potencjalnie posłużyć jako niebezpieczne narzędzie. Wprowadzono także obowiązek meldunkowy. Aby mu skutecznie zadośćuczynić, obcokrajowiec powinien zameldować się najpóźniej w ciągu doby od przekroczenia granicy, a obywatel Rosji, najpóźniej do 3 dób od przybycia do nowego miejsca zamieszkania. Zakazano także wjazdu autobusom do miast-gospodarzy, chyba że zostaną wyposażone $\mathrm{w}$ system nawigacji satelitarnej ERA-GLONASS, przekazujący służbom na bieżąco wszystkie niezbędne informacje, m.in o lokalizacji, kierunku i prędkości takich pojazdów, a ich kierowcy z wyprzedzeniem poinformują o planowanym wjeździe autobusu do miasta ${ }^{348}$.

Na czas trwania mistrzostw utworzono również zamknięte strefy powietrzne i wodne. Niektóre przedsiębiorstwa, zwłaszcza te korzystające z niebezpiecznych chemikaliów i innych potencjalnie groźnych substancji, zmuszone zostały zawiesić swoją działalność na czas turnieju. Wprowadzono również nakaz oznaczania w Komitecie Organizacyjnym Rosja-2018 urządzeń elektronicznych, które zamierza się wnieść na teren obiektu sportowego. W praktyce sprowadzało się to do umieszczenia na urządzeniu naklejki $\mathrm{z}$ kodem kreskowym lub ze zintegrowanym chipem elektronicznym. Większość powszechnych urządzeń takich jak telefony komórkowe, zestawy słuchawkowe Bluetooth, bransoletki elektroniczne, odtwarzacze muzyki i inne nie podlegały obowiązkowi oznaczania. Zakaz dotyczył zwłaszcza niewymienionych powyżej środków komunikacji, które mogłyby ewentualnie pozwolić grupom terrorystycznym na lepszą koordynację działań. Zaostrzono znacząco przepisy sanitarne i epidemiologiczne. Do dwóch tygodni przed rozpoczęciem mistrzostw, pracownicy sektora gastronomicznego musieli przejść przymusowe badania lekarskie, zwłaszcza pod kątem bakterii Escherichia coli i chorób układu pokarmowego. Nieposiadający niezbędnych

\footnotetext{
348 Безопасность ЧМ-2018: на земле, в небесах и на море, https://riafan.ru/1057672-bezopasnost-chm-2018na-zemle-v-nebesakh-i-na-more, (dostęp: 20.08.2019 r.).
} 
zaświadczeń lekarskich lub mający problemy zdrowotne zostali pozbawieni możliwości pracy $\mathrm{w}$ czasie mistrzostw. Ustawiono również specjalne kryteria medyczne dla kelnerów, pracowników hoteli, a nawet wolontariuszy, którzy musieli wykazać się dowodem na odbycie szczepień przeciwko wirusowemu zapaleniu wątroby typu A iczerwonce. Dodatkowo przeprowadzono kontrole restauracji i podawanych tam potraw, zwłaszcza pod kątem występowania $\mathrm{w}$ jedzeniu bakterii listerii i salmonelli.

W celu zapewnienia porządku, imprezy strzegło blisko 100 tysięcy funkcjonariuszy MSW. Zaangażowano siły Rosgwardii, OMON-u i służb specjalnych (zwłaszcza FSB). Według zapewnień ministra obrony Federacji Rosyjskiej - Siergieja Szojgu, ze strony wojska porządku strzegło ponad 10 tysięcy żołnierzy, ponad 2 tysiące jednostek techniki wojskowej w tym 32 okręty, 37 samolotów oraz 54 śmigłowce ${ }^{349}$. Przeprowadzano bardzo szczegółowe kontrole na granicach państwowych, zwłaszcza ze względu na fakt, że obywatelom ponad 30 państw zezwolono na bezwizowy wjazd do Rosji ${ }^{350}$. Oprócz tego kontrolowano kluczowe węzły komunikacyjne takie jak lotniska i dworce. Niektóre formy, takie jak prześwietlanie bagażu przed wejściem do metra, stały się dość uciążliwe, zwłaszcza dla stałych mieszkańców miast. W sposób bardzo dokładny kontrolowano także akredytowanych dziennikarzy ${ }^{351}$. Pozwoliło to także na większą możliwość kontrolowania przekazu medialnego poprzez możliwość ewentualnego odmówienia wydania akredytacji lub jej pozbawienia. Zakupiono i zainstalowano około 4 tysiące nowych systemów CCTV umożliwiające rozpoznawanie osób dzięki danym biometrycznym, ulepszone skanery bagażu oraz systemy do zwalczania dronów. Dla lepszej koordynacji służb ratowniczych wprowadzono protokół Jupiter G-3, umożliwiający dostarczanie zespołom bieżących informacji, pozwalający na skuteczniejsze planowanie trasy i aktualizację informacji o ruchu drogowym ${ }^{352}$. W wielu relacjach $\mathrm{z}$ imprezy podkreśla się wszechobecność patroli wojska i policji, które jednak rozmieszczono na tyle umiejętnie, aby nie rzucały się nadmiernie w oczy oraz nie psuły radosnej atmosfery imprezy sportowej ${ }^{353}$. Minister spraw zagranicznych FR - Siergiej Ławrow poinformował, że w celu profilaktyki zagrożenia terrorystycznego stworzony został międzyresortowy sztab operacyjny koordynujący wysiłki odpowiednich struktur siłowych. Oprócz tego nawiązano ścisłą współpracę z zagranicznymi partnerami, w tym w ramach otwartej dla wszystkich państw Konwencji Rady Europy ws. zintegrowanego podejścia do bezpieczeństwa, zabezpieczenia i obstugi podczas meczów piłki nożnej i innych imprez sportowych ${ }^{354}$. W ramach koordynacji działań na rzecz

349 Безопасность на ЧМ-2018 обеспечивали более 10 тыс. военных, 32 корабля, 37 самолетов, https://kubnews.ru/obshchestvo/2018/07/24/bezopasnost-na-chm-2018-obespechivali-bolee-10-tys-voennykh32-korablya-37-samoletov/ (20.08.2019 r.).

350 Rosyjskie władze wprowadziły w tej dziedzinie dosyć istotne zróżnicowanie. Najbardziej uprzywilejowaną grupą byli obywatele państw WNP. Mogli przebywać w Rosji do 90 dni, po tym okresie musieli zdobyć pozwolenie na pracę, naukę albo stały pobyt. Podobnie mieszkańcy Abchazji (Gruzja), Argentyny, Brazylii, Chile, Ekwadoru, Fidżi, Gwatemali, Izraela, Kolumbii, Nikaragui, Peru, Południowej Osetii (Gruzja)Serbii, Urugwaju oraz Wenezueli, którzy po upływie 90 dni powinni postarać się o wizę. Maksymalnie 30 dni bez wizy mogli w Rosji spędzić obywatele Bośni i Hercegowiny, Czarnogóry, Kuby Tajlandii oraz Turcji, a mieszkańcy Hongkongu tylko do 14 dni.

351 Janas P., Rosja. Bezpieczeństwo musi być, wyjątków (prawie) nie ma, https://gazetawroclawska.pl/rosjabezpieczenstwo-musi-byc-wyjatkow-prawie-nie-ma-komentarz/ar/13263990, (20.08.2019 r.).

352 Case study: How Russia improved security for the 2018 FIFA World Cup, http://www.securika-moscow.ru/enGB/press/news/Russia-World-Cup-2018-Security.aspx, (20.08.2019 r.).

353 Bublewicz B., $O$ bezpieczeństwie $w$ Rosji $w$ trakcie mundialu, https://sport.onet.pl/mundial2018/reprezentacja-polski/ms-2018-bezpieczenstwo-w-rosji-na-najwyzszym-poziomie/fwjkw9d, (20.08.2019 r.). 354 Lawrow o priorytetach Rosji na MŚ 2018, https://pl.sputniknews.com/worldcup-2018archive/201711246775195-Lawrow-bezpieczenstwo-Mistrzostwa-Swiata-2018-Rosja/, (20.08.2019 r.). 
bezpieczeństwa powołano centrum międzynarodowej współpracy policji. W jego skład weszli funkcjonariusze ze wszystkich państw reprezentowanych na mistrzostwach oraz policjanci z państwa-gospodarza mundialu w 2022 - Kataru. Ilość zaproszonych funkcjonariuszy z danego państwa wynikała z oszacowania potencjalnego ryzyka związanego z kibicami z danego kraju przez rosyjską policję. Warto nadmienić, że policjantów z Polski było 6, co stanowiło obok kilku innych grup największą reprezentację spośród państw występujących na mistrzostwach $^{355}$. Ze strony rosyjskiej w składzie centrum znaleźli się specjaliści w zakresie przestępczości, migracji, porządku i bezpieczeństwa publicznego, eksperci $\mathrm{w}$ dziedzinie bezpieczeństwa dużych międzynarodowych imprez, kontaktu z mediami, oraz thumacze. Centrum otworzono 12 czerwca 2018 r. w dniu święta narodowego - Dnia Rosji.

\section{Cyberbezpieczeństwo}

Zagadnienia dotyczące zapewnienia bezpieczeństwa $\mathrm{w}$ trakcie rosyjskiej imprezy budziły poważne obawy pośród kibiców i ekspertów ${ }^{356}$. Jeszcze przed rozpoczęciem mistrzostw, w Internecie zaczęły ukazywać się liczne artykuły zarówno na stronach anglojęzycznych jak i polskich, poruszające zagadnienia bezpieczeństwa osobowego. Część z nich była ukierunkowana na uchronienie turystów przed zapłaceniem nieproporcjonalnie wysokich cen za usługi, zwłaszcza za transport oraz noclegi ${ }^{357}$. Inne $\mathrm{z}$ kolei w bardzo profesjonalny sposób przestrzegały przed zagrożeniami ze strony cyberprzestępców oraz oficerów służb specjalnych, mogących próbować uzyskać dostęp do danych zgromadzonych w urządzeniach należących do kibiców, takich jak laptopy i telefony komórkowe ${ }^{358}$. Rekomendowano m.in. korzystanie z VPN (Virtual Private Network), zabezpieczenie sprzętu w kontekście TP (tajnego przeszukania), niepozostawianie sprzętu bez opieki, korzystanie z szyfrowanych komunikatorów oraz uwzględnienie faktu, że być może jest się obserwowanym, istotnego zwłaszcza w przypadku wprowadzania haseł dostępu do urządzeń. Jeszcze inne serwisy z kolei, przestrzegały przed niebezpieczeństwem w postaci kampanii phishingowych skierowanych przeciwko zagranicznym kibicom oraz fałszywymi stronami, podszywającymi się pod te oficjalne, oferującym sprzedaż biletów ${ }^{359}$.

To właśnie element cyberbezpieczeństwa był szeroko podnoszony w dyskursie publicznym. Według raportu firmy Kaspersky Lab ponad 20\% hotspotów Wi-Fi w miastachgospodarzach Mistrzostw Świata ma problemy w zakresie cyberbezpieczeństwa. Miasta o najwyższym odsetku niepewnych sieci Wi-Fi to Sankt Petersburg (37\%), Kaliningrad (35\%) oraz Rostów (32\%) ${ }^{360}$. Stowarzyszenie Piłki Nożnej Anglii (FA) rekomendowało członkom reprezentacji korzystanie z „własnego" Internetu i nieużywanie publicznej lub hotelowej sieci Wi-Fi, aby zapewnić, że poufne informacje, takie jak taktyka drużyny, nie wyciekną. Obawy

355 Bublewicz B., O bezpieczeństwie w...op.cit.

356 Warto nadmienić, że bezpieczeństwo na mundialu w Rosji było m.in. przedmiotem debaty eksperckiej pt. $C z y$ Mistrzostwa Świata $w$ Pitce Nożnej $w$ Rosji będa bezpieczne? Zorganizowanej przez Centrum Badań nad Terroryzmem Collegium Civitas 13 czerwca 2018 roku oraz programów telewizyjnych i radiowych.

357 Na co trzeba uważać podróżując na Mistrzostwa Świata do Rosji? O tym kibice musza pamiętać, https://niezalezna.pl/227386-na-co-trzeba-uwazac-podrozujac-na-mistrzostwa-swiata-do-rosji-o-tym-kibice-

musza-pamietac, (20.08.2019 r.).

358 Na co uważać jadąc do Rosji na Mistrzostwa Świata w Piłce Nożnej?, https://niebezpiecznik.pl/post/wyjazddo-rosji-na-co-uwazac-mundial/ oraz 2018 Soccer World Cup safety tips https://www.kaspersky.co.uk/blog/fifa2018-security/13740/, (20.08.2019 r.).

3592018 Fraud World Cup, https://securelist.com/2018-fraud-world-cup/85878/, (20.08.2019 r.).

360 FIFA public Wi-Fi guide: which host cities have the most secure networks? https://securelist.com/fifa-publicwi-fi-guide/85919/, (20.08.2019 r.). 
spotęgowane były również faktem, że rosyjscy hakerzy uchodzą za jednych z najlepszych na świecie oraz znani są z atakowania urządzeń mobilnych, tak jak chociażby w przypadku żołnierzy armii amerykańskiej stacjonujących w Polsce i krajach nadbałtyckich, kiedy ich celem ataku stały się telefony żołnierzy ${ }^{361}$. Za inny ich sukces, chociażby tylko w samej dziedzinie sportu, można uznać kradzież i opublikowanie raportów WADA przez grupę Fancy Bears. Byli oni również najprawdopodobniej odpowiedzialni za sabotowanie otwarcia igrzysk zimowych w Pjongczangu w 2018 roku, w których uniemożliwiono zawodnikom z Rosji reprezentowania swoich barw narodowych, jako rezultat sankcji za masowe stosowanie dopingu.

Z drugiej strony to Rosja jako gospodarz imprezy o tak wielkim znaczeniu, znalazła się w centrum zainteresowania cyberprzestępców i hakerów. W trakcie mundialu odnotowano aż 25 mln cyberataków, o czym poinformował opinię publiczną sam Władimir Putin ${ }^{362}$. Dla porównania strony związane z igrzyskami w Pekinie w 2008 roku napotkało więcej, bo aż około 12 milionów ataków online dziennie ${ }^{363}$. Pomimo tego liczba ataków na rosyjskie systemy była bardzo znacząca, a pomimo tego infrastruktura internetowa związana m.in. ze sprzedażą biletów na mecze i środki komunikacji działały sprawnie od początku do momentu zakończenia mistrzostw, co można uznać za sukces służb odpowiedzialnych za cyberbezpieczeństwo.

\section{Przeciwdzialanie incydentom o charakterze chuligańskim}

Przed mistrzostwami szczególnie duże obawy wiązano z zagrożeniem ze strony rosyjskich pseudokibiców. Według doniesień medialnych, mieli oni porozumieć się z ich odpowiednikami z Argentyny, aby wspólnymi siłami zaatakować kibiców z Anglii. Miało to stanowić kolejną odsłonę walk zapoczątkowanych w trakcie Euro 2016 we Francji, gdzie zorganizowana grupa około 200 uzbrojonych mężczyzn z Rosji starła się z Anglikami w Starym Porcie w Marsylii. W efekcie takiej zapowiedzi blisko 10 tysięcy kibiców z wysp miało zrezygnować z przyjazdu na mistrzostwa ${ }^{364}$. Pomimo tego, do incydentów takiego rodzaju nie doszło, a pseudokibice byli zupełnie „niewidoczni” w przekazach medialnych. Podobnie nie zostały odnotowane żadne incydenty o charakterze rasistowskim, które dosyć regularnie towarzyszą rozgrywkom ligowym w Rosji. Było to możliwe zwłaszcza dzięki ingerencji władzy w środowisko fanatów, jak w Rosji mówi się na kibiców, co było poprzedzone dokładnym jego rozpoznaniem.

Warto zaznaczyć, że w przeciwieństwie do innych krajów, gdzie najważniejsze grupy kibicowskie powstają oddolnie, w Rosji główny związek kibiców czyli Wszechrosyjski Związek Kibiców (WOB) powstał z inicjatywy władzy. Jego pomysłodawcą i założycielem w 2007 roku był wieloletni minister sportu, odpowiadającego m.in. za funkcjonowanie systemu

361 Rosjanie włamuja się do telefonów żotnierzy NATO na wschodniej flance, za: https://www.polskieradio24.pl/5/3/Artykul/1876967,Rosjanie-wlamuja-sie-do-telefonow-zolnierzy-NATO-nawschodniej-flance, (20.08.2019 r.).

362 Długosz D., Rosja $w$ trakcie Mundialu odnotowała 25 mln cyberataków, za: https:/www.komputerswiat.pl/aktualnosci/bezpieczenstwo/rosja-w-trakcie-mundialu-odnotowala-25-mlncyberatakow/w0e5xvw, (20.08.2019 r.).

363 Cyberbezpieczeństwo na międzynarodowych imprezach sportowych, takich jak Mistrzostwa Świata w Pitce Nożnej 2018, za: https://itd24.pl/quick-heal-seqrite/cyberbezpieczenstwo-na-miedzynarodowych-imprezachsportowych-takich-jak-mistrzostwa-swiata-w-pilce-noznej-2018/, (20.08.2019 r.).

364 Szykuje się skandal na MŚ 2018? Bezpieczeństwo kibiców zagrożone. Kibole z Rosji i Argentyny chca zaatakować angielskich fanów, za: http://www.sport.pl/pilka/7,64946,23248790,szykuje-sie-skandal-na-ms-2018pseudokibice-z-rosji-i-argentyny.html, (20.08.2019 r.). 
dopingowego w Rosji oraz późniejszy wicepremier - Witalij Mutko. Na czele związku stanął Aleksander Szprygin. Kontakty Kremla ze środowiskiem kibicowskim zintensyfikowały się w grudniu 2010 roku, kiedy to doszło do głośnego zabójstwa kibica - Jegora Swiridowa ${ }^{365}$. Organizacja była posłuszna władzy i realizowała jej polecenia. W trakcie Euro 2012 odbywającego się w Polsce i na Ukrainie kibice zorganizowali marsz na cześć przypadającego w dniu 12 czerwca święta - Dnia Rosji. Akcja miała miejsce w trakcie przemarszu kibiców na mecz na PGE Stadion Narodowy w Warszawie. Ostatecznie doszło do bójki, w wyniku której ucierpiało 11 policjantów i 10 kibiców. W ramach wsparcia akcji władze udostępniły Szpryginowi i WOB cztery rządowe samoloty. Kolejną ważną imprezą, którą zakłócili kibice z Rosji, były Miszostwa Europy we Francji w 2016 roku. Szczególną uwagę zwraca ich stopień organizacji, zdyscyplinowania i uzbrojenia, odbiegający znacznie od chuligańskich standardów. Zaopatrzeni $w$ gumowe ochraniacze na zęby, w teleskopowe pałki do bicia. Zakładali koszulki angielskich klubów, aby zaatakować wroga od tyłu ${ }^{366}$. Przed wspomnianym epizodem w trakcie Euro 2016 we Francji i na krótko po nim, współpraca pomiędzy kibicami i władzami układała się bardzo dobrze. Prezydent Putin żartował z wydarzeń $\mathrm{z}$ Marsylii zastanawiając się jak 200 kibiców z Rosji mogło pobić kilka tysięcy Anglików ${ }^{367}$. Spekuluje się nawet, że akcja miała na celu zebranie materiałów kompromitujących, wykorzystanych później do przeciwdziałania chuliganom.

Dopiero z biegiem czasu, wraz ze zbliżaniem się terminu rozpoczęcia rosyjskich mistrzostw świata, władze postanowiły jednoznacznie zredukować zagrożenie ze strony fanatów Policja dokładnie namierzyła osoby odpowiedzialne za wydarzenia z Francji i objęła je kontrolą. Sam Aleksander Szprygin był nawet tymczasowo zatrzymany, a działalność jego Wszechrosyjskiego Związku Kibiców została zawieszona ${ }^{368}$. Najgroźniejszym kibicom odmówiono wydania uprawniającego do wejścia na stadion FanID, a część z nich profilaktycznie wolała nawet opuścić Rosję na czas mistrzostw, aby nie paść ofiarą prowokacji ze strony służb. Dodatkowo do Rosji nie wpuszczono ok. 3 tysięcy zagranicznych kibiców, notowanych za naruszanie porządku w trakcie imprez masowych. Informacje o potencjalnym zagrożeniu otrzymano głównie z baz Interpolu oraz od związków piłki nożnej poszczególnych państw. Dzięki temu żadne znaczące incydenty o charakterze chuligańskim w trakcie mundialu nie miały miejsca.

\section{Terroryzm}

Zagrożenie ze strony ugrupowań fundamentalistów religijnych należało do jednych z najpoważniejszych oraz najbardziej prawdopodobnych potencjalnych źródeł niebezpieczeństwa podczas mistrzostw. Z tym zagadnieniem władze rosyjskie zetknęły się już wcześniej w trakcie organizacji igrzysk w 2014 roku. Wówczas to udało się przeciwdziałać

\footnotetext{
365 Swiridow, kibic klubu Spartak Moskwa, został zamordowany przez pochodzącego z Kaukazu Asłana Czerkiesowa. Za cichym przyzwoleniem władz doszło do jednych z największych w historii zamieszek na tle etnicznym w Moskwie, w wyniku których zatrzymano 68 osób. Ówczesny premier Władimir Putin uczestniczył w ceremoniach pogrzebowych Swiridowa, gdzie miał zjednać sobie kibiców i poznać prezesa WOB - Aleksandra Szprygina.

366 Imielski R., Leniarski R., Najwjażniejszy mecz Kreml, Warszawa 2018, s.75.

367 Euro 2016: Vladimir Putin mocks 'thousands of England fans beaten up by 200 Russians' in violent clashes za: https://www.independent.co.uk/news/people/euro-2016-vladimir-putin-russia-violence-england-fan-fights-doubta7087971.html (20.08.2019 r.).

368 Dobek D., Gdzie ci kibole? Za:, https://sport.onet.pl/mundial-2018/reprezentacja-rosji/mundial-2018mistrzostwa-swiata-w-rosji-bez-chuliganow/039kd11 (20.08.2019 r.).
} 
zagrożeniu na kilka sposobów. Wyeliminowano część przywódców ugrupowań, w tym również samego Doku Umarowa - samozwańczego emira Emiratu Kaukaskiego. Zwiększono obecność wojskową i zintensyfikowano działania służb oraz częściowo „wyeksportowano” zagrożenie dzięki stopniowemu odpływowi potencjalnych rekrutów do organizacji terrorystycznych na Bliski Wschód, któremu nie przeszkadzała, a nawet dosyć aktywnie sprzyjała FSB. O skuteczności przyjętej przez władze strategii świadczy fakt, że liczba zamachów terrorystycznych w Rosji została wydatnie zredukowana. Zjawisko to dotyczy zwłaszcza zamachów na dużą skalę. Od ataków samobójczych w Wołgogradzie w grudniu 2013 r., w których zginęły 34 osoby cywilne, jedynym atakiem o podobniej skali od tamtej pory był zamach bombowy na metro w Petersburgu w kwietniu 2017 r., co jak na standardy sytuacji bezpieczeństwa w Rosji stanowi względnie długi okres spokoju. Do tego warto nadmienić, że sprawca zamachu na metro w Petersburgu urodził się w Kirgistanie, a nie na Kaukazie Północnym.

Jednakże uwarunkowania bezpieczeństwa od tamtego czasu uległy zmianie. Dodatkowym czynnikiem zagrożenia był fakt, że od momentu upadku struktur ISIS w Iraku i Syrii nasiliło się zjawisko powrotu tzw. foreign fighetrs do krajów pochodzenia, w tym również do Rosji. Szacuje się, że od czasu powstania ISIS nawet 5-7 tys. obywateli rosyjskich - głównie z Dagestanu, Czeczenii, Tatarstanu oraz byłych republik radzieckich w Azji Środkowej wyjechało na Bliski Wschód, aby walczyć po stronie Daesh. Wielu z nich, przeszkolonych przez ISIS, często dysponujących również doświadczeniem bojowym z konfliktów na obszarze byłego ZSRR, a zwłaszcza weteranów wojen czeczeńskich powróciło do Rosji i mogło stanowić szczególnie duże zagrożenie dla nadchodzących mistrzostw. Szacuje się, że około 400 bojowników wróciło do Rosji.

W październiku 2017 roku terroryści podjęli pierwsze próby zastraszania kibiców i organizatorów mistrzostw. Ukazały się plakaty $\mathrm{z}$ tytułami „Nie będziecie cieszyć się bezpieczeństwem, dopóki nie żyjemy w muzułmańskich krajach” oraz „Nadal będziemy terroryzować was i rujnować wasze życia". ISIS opublikowało w Internecie zdjęcia prezydenta Donalda Trumpa oraz Władimira Putina $\mathrm{z}$ dziurami $\mathrm{w}$ głowie po kulach, jako tarcz strzelniczych z napisem „Czekam na szansę aby ich dopaść. Kalifat będzie grobem dla Amerykanów i Rosjan". Kampania ukierunkowana stricte pod mistrzostwa miała miejsce w kwietniu 2018 roku. Na swoim plakacie ISIS przedstawia Putina na stadionie, który jest na celowniku terrorystów z podpisem „Rosja - 2018. Putin, jesteś niewierny. Zapłacisz za zabijanie muzułmanów". W maju francuska grupa medialna al-Nur Media Center, związana z ISIS opublikowała szczególnie dla aspirujących bojowników grafikę z państwami biorącymi udział w mundialu wraz z napisem "Choisis ta Cible" (Wybierz swój cel) ${ }^{369}$.

W odpowiedzi na zagrożenie rosyjskie służby kontynuowały działalność ukierunkowaną na fizyczną likwidację przywódców ugrupowań terrorystycznych. Od 2014 roku śmierć poniosło kolejnych 3 przywódców Emiratu Kaukaskiego. W kwietniu 2015 roku został zabity Ali Abu-Muchammad, a w sierpniu tego samego roku jego następca Magomied Alijewicz Sulejmanow. Ostatnim znanym przywódcą organizacji był Zalim Borisowicz Szebzuchow, zastrzelony w sierpniu 2016 roku w Petersburgu. Na jego miejsce nie wyznaczono żadnego oficjalnego następcy. Główne ugrupowania zostały rozbite i pozbawione

369 Kobierski Ł., Jak Rosja zadbała o bezpieczeństwo mistrzostw świata 2018 roku? za: http://ine.org.pl/jak-rosjazadbala-o-bezpieczenstwo-mistrzostw-swiata-2018/ (20.08.2019 r.). 
przywództwa, jednakże terroryści dostosowali się do nowych uwarunkowań. Zaczęli organizować się $\mathrm{w}$ bardzo małych komórkach po dwóch lub trzech mężczyzn, na tyle niewielkich, że wykrycie przez służby stało się prawie niemożliwe. Pomimo wyeliminowania większości weteranów wojen czeczeńskich w ich miejsce zaczęli się pojawiać się młodzi, urodzeni w latach 90-tych mężczyźni, często stosujący taktykę tzw. samotnych wilków (lone wolves).

Do ważniejszych zamachów dokonanych przez „nową gnerację” terrorystów można zaliczyć atak przy pomocy broni białej przeprowadzony przez mieszkańca Dagestanu w syberyjskim mieście Surgut w sierpniu 2017 roku, w wyniku którego rannych zostało 8 osób oraz strzelaninę z członkiem ISIS w miejscowości Kizlar w Dagestanie w lutym 2018 roku, W wyniku której śmierć poniosło 5 osób, a 4 zostały ranne. Na reakcję ze strony władz nie trzeba było długo czekać. W połowie kwietnia 2018 roku FSB rozbiło w Rostowie na Donem (miasto-gospodarz mistrzostw) komórkę ISIS. Jeden z bojowników zdetonował ładunek wybuchowy i zginął, a trzech kolejnych zatrzymano ${ }^{370}$. Nagłośnienie tej akcji i innych do niej podobnych miało na celu przekonanie opinii publicznej, ze sytuacja jest pod kontrolą służb a kibice przyjeżdżający na mistrzostwa nie mają powodów do obaw. Ostatecznie wysiłki służb bezpieczeństwa zakończyły się sukcesem, w czasie mistrzostw nie doszło do żadnych aktów terroru. Według słów szefa FSB - Aleksandra Bortnikowa, służba zapobiegła przynajmniej siedmiu próbom ataków na kibiców, w tym przy pomocy drona ${ }^{371}$.

\section{Inne aspekty bezpieczeństwa}

Dość nieoczekiwanie źródłem zagrożenia mogła stać się wybudowana na potrzeby mistrzostw infrastruktura. Stadion w Wołgogradzie i jego najbliższa okolica uległy znacznym zniszczeniom w wyniku intensywnych deszczy, które miały miejsce 7 lipca 2018 roku, czyli jeszcze przed zakończeniem mistrzostw. Uszkodzeniu uległ wschodni nasyp oraz zlokalizowana na nim promenada okalająca stadion. Przerwane zostały również instalacje umieszczone w ziemi, a tony piachu spłynęły w stronę Wołgi. Warto zauważyć, że inne obiekty, takie jak pobliski Kurhan Mamaja pozostały w stanie nienaruszonym, co świadczy o niskiej jakości nowo wybudowanych instalacji, pomimo rekordowo dużych nakładów pieniężnych przeznaczonych na imprezę ${ }^{372}$. Szczęśliwie dla władz miało to miejsce już po zakończeniu fazy grupowej, której mecze gościł stadion. Podobne zjawisko miało miejsce w Niżnym Nowogrodzie, gdzie częściowo osunęła się droga prowadząca na stadion. Doniesienia tego rodzaju stanowią poważny cios wymierzony w propagandowy wydźwięk imprezy, godzą zwłaszcza w wizerunek Rosji jako nowoczesnego państwa i sprawnego organizatora.

Władze podjęły również starania w celu powstrzymania nielegalnej manipulacji biletami na mecze. Karano zarówno spekulowanie ich cenami oraz próby ich podrabiania. Wysokość sankcji zależała od tego, kto popełnił przestępstwo. W przypadku spekulacji, osoby fizyczne były karane grzywną w wysokości 20-25- krotności ceny biletu, ale nie mniej niż 50 tysięcy rubli. Osoby prawne musiały zapłacić od 500 tysięcy do 1 miliona rubli, a ich działalność zawieszana była na 90 dni. Najsurowsze kary groziły za podrabianie biletów. Były

\footnotetext{
370 Ibidem.

371 Russia claims it foiled terrorist plans for World Cup attacks, za: https:/www.independent.co.uk/sport/football/international/russia-claims-foiled-world-cup-terrorist-attackdrones-vladimir-putin-video-a8621496.html (20.08.2019 r.).

372 Do tej pory szacuje się, że mistrzostwa mogły kosztować Rosję około 14 mld S, z czego dużą część pochłonęła, tradycyjnie wysoka w przypadku imprez sportowych w Rosji, korupcja.
} 
to odpowiednio: grzywna w wysokości 50-70 tysięcy rubli dla osób fizycznych, 150-200 tysięcy rubli dla urzędników oraz 1,5 miliona rubli dla osób prawnych. Regulacją w tej dziedzinie zajmowała się agencja rządowa - Rospotrebnadzor ${ }^{373}$.

W celu ograniczenia nagłego wzrostu cen za wynajęcie pokoju hotelowego, władze wprowadziły państwową regulację kosztów usług hotelowych na podstawie art. 36 ustawy federalnej z 07.06.2013 $\mathrm{nr} 108^{374}$. Przepisy te wprowadzono jeszcze przed Pucharem Konfederacji, imprezą poprzedzającą mistrzostwa o około rok. Wiązało się to $\mathrm{z}$ uprzednią koniecznością poddania się reżimowi gwiazdkowemu przez wszystkie hotele. Z kolei maksymalne ceny zakwaterowania w hotelach miejskich w okresie od 14 maja do 15 sierpnia 2018 r. zawarto w dekrecie rządu Federacji Rosyjskiej nr 89 z dnia 10.02 .2016 r $^{375}$. W ten sposób wyznaczono najwyższy pułap cenowy dla pokoju hotelowego $\mathrm{w}$ danym mieście o wskazanej ilości gwiazdek. Najwyższe ceny były w Petersburgu oraz w Moskwie. Pozostałe miasta oferowały tańsze pokoje, jednakże powtarzającym się często zjawiskiem było wypowiadanie rezerwacji i podnoszenie ceny wraz z coraz większą ilością zainteresowanych turystów ${ }^{376}$. Pomimo tego nie udało się uniknąć podwyższania cen za inne usługi, szczególnie w obszarze transportu osób.

Maksymalne opłaty za pokój hotelowy w Moskwie w trakcie trwania mistrzostw

\begin{tabular}{|c|c|c|}
\hline \multirow{2}{*}{ llość gwiazdek } & \multicolumn{2}{|c|}{ Maksymalna cena pokoju } \\
\cline { 2 - 3 } & Apartament & Zwykły standard \\
\hline 5 & 650 tys. rubli & 50 tys. rubli \\
\hline 4 & 85 tys. rubli & 20 tys. rubli \\
\hline 3 & \multicolumn{2}{|c|}{12250 rubli } \\
\hline 2 & \multicolumn{2}{|c|}{7410 rubli } \\
\hline 1 & 6970 rubli \\
\hline Bez gwiazdek & \multicolumn{2}{|c|}{3480 rubli } \\
\hline
\end{tabular}

Opracowanie własne

Należy również wspomnieć, że w omawianej sytuacji bezpieczeństwa, mistrzostwa w Rosji stanowiły nie tylko wyzwanie, ale również szansę. Dla służb była to okazja na pozyskanie nowych i obsługę istniejących aktywów osobowych. Mogły one skutecznie prowokować zaistnienie sytuacji kompromitujących i zbierać materiały, które mogą

\footnotetext{
373 Федеральная служба по надзору в сфере защиты прав потребителей и благополучия человека.

374 Федеральный закон от 07.06.2013 N 108-Ф3 (ред. от 01.05.2019) «О подготовке и проведении в РФ чемпионата мира по футболу FIFA 2018 года, Кубка конфедераций FIFA 2017 года, чемпионата Европы по футболу UEFA 2020 года и внесении изменений в отдельные законодательные акты РФ» 375 Постановление Правительства РФ от 10.02.2016 №89.

376 На ЧМ-2018 будут беспречедентные меры безопасности, za: https://www.pnp.ru/social/na-chm-2018budut-besprecedentnye-mery-bezopasnosti.html (20.8.2019 r.).
} 
w przyszłości posłużyć chociażby do szantażu albo dyskredytacji danej osoby. W trakcie mistrzostw mogły one również typować odpowiednie osoby, celem nawiązania w przyszłości współpracy oraz przy pomocy naturalnej legendy, jaką jest pobyt w kraju-gospodarzu mistrzostw, odbierać materiały, przekazywać środki oraz spotykać się z zawerbowanymi źródłami. Podejmowały również wzmożone wysiłki polegające na kontrolowaniu przyjezdnych o czym przekonali się dziennikarze BBC, którzy wykryli obserwację towarzyszącą ${ }^{377}$. Dla administracji Putina była to okazja do uniemożliwienia publicznego oprotestowania przez społeczeństwo niepopularnych reform, ze względu na obowiązywanie prezydenckiego dekretu zakazującego tego typu zgromadzeń, uzasadnionego względami bezpieczeństwa imprezy. Do najistotniejszych reform, wprowadzanych niejako pod osłoną mistrzostw, należało chociażby podwyższenie wieku emerytalnego. Nie można oprzeć się wrażeniu, że była to świadoma i przemyślana strategia władz, zwłaszcza, że wydłużyły one czas obowiązywania tymczasowych regulacji aż do września 2018 roku.

\section{Podsumowanie}

Ostatecznie, nie licząc m.in. bijatyki z udziałem argentyńskich kibiców w Niżnym Nowogrodzie czy dewastacji pociągu przez pijanego angielskiego kibica, w trakcie trwania całej imprezy nie doszło do większych naruszeń porządku publicznego. Incydenty te nie były nagłaśniane, a kary dla kibiców były symboliczne378. Do tego w licznych relacjach zagranicznych turystów przedstawiciele rosyjskich służb jawili się jako ludzie pomocni i uprzejmi, co nie korespondowało $\mathrm{z}$ ich utrwalonym wizerunkiem, opartym głównie o telewizyjne relacje $\mathrm{z}$ tłumienia zamieszek. To właśnie $\mathrm{w}$ dziedzinie zapewnienia bezpieczeństwa można upatrywać się najlepszych rezultatów organizatorów, co dowodzi sprawności działania służb i aparatu bezpieczeństwa. Dzięki takiemu obrotowi spraw Rosja utrwaliła swój wizerunek bezpiecznego i silnego państwa. Nie można jednak oprzeć się wrażeniu, że co prawda, dzięki dużym nakładom sił i środków udało się zapobiec potencjalnie niebezpiecznym sytuacjom, to stan bezpieczeństwa w Rosji nie uległ szczególnej poprawie. Problemy są dużo głębsze i wymagają rozwiązań systemowych, zwłaszcza te dotyczące problemu terroryzmu, m.in. postępująca radykalizacja wśród migrantów zarobkowych z Azji Centralnej wobec pogarszających się warunków pracy. Podobnie sytuacja prezentuje się w przypadku pseudokibiców, których aktywność została jedynie ,zawieszona” na czas imprezy.

\section{Streszczenie:}

Artykuł rozpatruje aspekt bezpieczeństwa Mistrzostw Świata w Piłce Nożnej w 2018 r. a propagandy Kremla. Za przedmiot analizy posłużył wspomniany mundial w Rosji - jako przykład z jednej strony najbardziej aktualny, a $z$ drugiej jako przypadek wymagający największych nakładów i stanowiący największe wyzwanie dla służb. W artykule poruszane

377 How a BBC crew was followed in World Cup 2018 Russia za: https://www.bbc.com/news/av/world-europe44388968/how-a-bbc-crew-was-followed-in-world-cup-2018-russia (20.8.2019 r.).

378 I. Wiśniewska, J. Rogoża, Mundial w Rosji - igrzyska zamiast chleba? Za: https://www.osw.waw.pl/pl/publikacje/komentarze-osw/2018-09-17/mundial-w-rosji-igrzyska-zamiast-chleba (20.8.2019 r.). 
zostały takie zjawiska jak: dziłąnia legislacyjne i operacyjne w Rosji wobec Mundialu terroryzm, cyberterroryzm oraz zachowania chuligańskie.

\section{Słowa klucz:}

Mistrostwa Świata w Piłce nożnej 2018, propaganda, polityka, bezpiecześntwo, Rosja

\section{Keywords:}

Football World Cup 2018, policy, seciurity, Russia

\section{Bibliografia:}

1. Aris Ben, Russia's Use of Sport in Regional Development Policy [w:] Russian Analytical Digest, Forschungsstelle Osteuropa Bremen and Center for Security Studies, "Zürich Research Centre for East European Studies", Brema/Zurych 2011, nr 95.

2. Castro e Andreia Soares, The 2018 FIFA World Cup: The Gains and Constraints of Russia's Soft Power of Attraction Through Football and Sports, [w:] Public Diplomacy of Rising and Regional Powers, Stambuł 2018, nr 3.

3. Imielski Roman, Leniarski Radosław, Najwjażniejszy mecz Kremla, Warszawa 2018.

4. Jakubowski Jakub, Wielkie imprezy sportowe w stużbie budowania wizerunku państw. Przykład grupy BRIC [w:] Refleksje, Poznań 2012.

5. Jokisipilä Markku, World Champions Bred by National Champions: the Role of StateOwned Corporate Giants in Russian Sports [w:] Russian Analytical Digest, Forschungsstelle Osteuropa Bremen and Center for Security Studies, Zürich Research Centre for East European Studies, Brema/Zurych 2011, nr 95.

6. Karczewski Maciej, Sport $w$ stosunkach międzynarodowych. Wstęp do teorii [w:] Refleksje, numer specjalny, Poznań 2012.

7. Kobierecki Michał Marcin, Polityka sportowa i polityka sportu w świetle naukowego piśmiennictwa anglosaskiego [w:] Athenaeum. Polskie Studia Politologiczne, Toruń 2014, nr 43.

8. Kobierecki Michał Marcin, Upolitycznienie sportu jako nastepstwo konfrontacji politycznej państw [w:] Przeglad Politologiczny, Poznań 2016, nr 1.

9. Makarychev Andrey, Yatsuk Alexandra, From Sochi-2014 to FIFA - 2018: a fading sovereignty? [w:] Sport In Society, Abingdon 2017 , nr 20.

10. Miazek Artur, MKOL i FIFA jako aktorzy stosunków międzynarodowych, Warszawa 2019.

11. Młodzikowski Grzegorz, Polityka i sport, Warszawa 1979.

12. Podleśny Artur, Polityka sportowa Zwiąku Radzieckiego i Federacji Rosyjskiej, Warszawa 2019. 
13. Polus Andrzej (red.), Sport w stosunkach międzynarodowych, Toruń 2009.

14. Wiśniewska Iwona, Rogoża Jadwiga, Mundial w Rosji-igrzyska zamiast chleba? 2018.

15. Włodkowska-Bagan Agata, Softpower w polityce zagranicznej Federacji Rosyjskiej wobec państw ,, bliskiej zagranicy”, [w:] Kwartalnik Naukowy OAP UW "e-Politikon", Warszawa 2012, nr 3. 